\title{
Wpływ promieniowania rozproszonego na jakość obrazu na radiogramie
}

\section{Scattered radiation influence on the image quality of the radiograph}

\section{Streszczenie}

Przedstawiono wpływ promieniowania rozproszonego na jakość obrazu na radiogramie. Omówiono zjawiska fizyczne towarzyszące promieniowaniu rozproszonemu oraz jego praktyczne skutki. Zaprezentowano przykłady badania wpływu promieniowania rozproszonego na jakość obrazu na radiogramie dla różnych obiektów, uwzględniając wpływ promieniowania rozproszonego od obiektów znajdujących się poza błoną oraz niezgodności w obliczeniach czasów ekspozycji.

\section{Wstęp}

W wyniku zjawiska rozpraszania promieniowania pierwotnego tworzy się promieniowanie wtórne o mniejszej energii fotonów. Promieniowanie to rozchodzi się po znacznie dłuższych drogach w elemencie badanym, w wyniku zmiany kierunku promieniowania. Zdolność przenikania promieniowania pierwotnego jest więc większa niż promieniowania rozproszonego. Promieniowanie rozproszone jednak, oddziałując na błonę radiograficzną, powoduje dodatkowe jej zaczernienie, w wyniku czego kontrast radiologiczny obiektu pogarsza się. Małym kontrastem radiologicznym obiektu charakteryzują się materiały o dużym współczynniku rozproszenia promieniowania.

\section{Promieniowanie rozproszone}

Promieniowanie rozproszone powstaje w badanym obiekcie, obok niego, za nim, w kasetach, okładkach ołowianych, ekranie i innych przedmiotach znajdujących się obok badanego elementu. Oddziałując na błonę, powoduje pogorszenie ostrości i kontrastu

Dr hab. inż. Jacek Słania, prof IS - Politechnika Częstochowska, mgr Kamila Sołtys - Laboratorium Spawalnicze GAMMA - MONTEX, Częstochowa. obrazu radiograficznego. Występowanie promieniowania rozproszonego powinno być sprawdzane przez zastosowanie ołowianej litery B umieszczonej na kasecie radiograficznej po stronie przeciwnej do strony źródła promieniowania [1].

Jeżeli na wywołanym radiogramie widoczny jest jasny obraz litery $B$, to zastosowana technika radiograficzna nie eliminuje promieniowania rozproszonego od obiektów znajdujących się poza błoną, takich jak ściana czy podłoga. Należy więc zastosować np. płytę ołowianą umieszczoną za błoną. W celu zabezpieczenia przed promieniowaniem rozproszonym można zastosować osłony i kolimatory, które mają ograniczać szerokość wiązki promieniowania do badanego obszaru [2]. Rozwiązania te dotyczą ochrony przed promieniowaniem rozproszonym powstającym na zewnątrz badanego obiektu. Jeżeli jednak promieniowanie rozproszone powstaje w samym obiekcie badanym, trudno jest je wyeliminować. Wpływ promieniowania rozproszonego na powstanie obrazu radiograficznego jest bardzo istotny.

Podstawową wadą tego promieniowania jest zmniejszenie kontrastu i ostrości uzyskiwanego obrazu i związane z tym pogorszenie wykrywalności niezgodności [3].

Osoby wykonujące badania radiograficzne muszą uwzględniać wpływ promieniowania rozproszonego, a co za tym idzie - planowanie odpowiednich technik badań radiograficznych, dobór energii źródła promieniowania, okładek wzmacniających, a także istnieje konieczność korygowania czasów ekspozycji. 
Promieniowanie rozproszone jest związane ze zjawiskami fizycznymi, które zostaną przedstawione w tym artykule.

\section{Miejsca powstawania promieniowania rozproszonego}

Rozproszenie wewnętrzne - rozproszenie występujące $w$ badanym elemencie (rys. 1). Promieniowanie to nie wytwarza obrazu użytecznego na błonie, lecz stanowi szkodliwe tło promieniowania, które powoduje dodatkowe, w miarę równomierne zaczernienie błony [4].

Promieniowanie to zaciemnia obraz krawędzi, otworów i innych szczegółów badanego elementu.

Wpływ promieniowania rozproszonego na jakość uzyskanego obrazu radiograficznego zależy m.in. od energii promieniowania pierwotnego. Im większa jest energia promieniowania pierwotnego, tym większa część promieniowania rozpraszana jest $w$ kierunku wiązki pierwotnej. Promienie rozproszone we wszystkich kierunkach powoduja równomierne dodatkowe zaczernienie błony. Przy użyciu promieniowania twardego kierunek promieni rozproszonych jest zbliżony do kierunku padania promieni pierwotnych, a nie powoduje więc znacznego pogorszenia kontrastu i ostrości obrazu radiograficznego.

Na rysunku 2 przedstawiono wpływ grubości badanego elementu oraz energii promieniowania pierwotnego (Ir 192, Cs137, Co 60) na wielkość promieniowania rozproszonego. Widać, że rozproszenie maleje ze wzrostem energii promieniowania pierwotnego, jednak wielkość tego rozproszenia jest zawsze duża. Wielkość promieniowania rozproszenia rośnie wraz z grubością badanego elementu oraz zależy od gęstości materiału. Rozproszenie promieniowania jest tym mniejsze im gęstość materiału jest większa [4].

Rozproszenie boczne - jest to rozproszenie promieniowania od ścian lub obiektów znajdujących się w sąsiedztwie badanego elementu lub od jego części. Promienie wnikają $z$ boku do badanego elementu. Promieniowanie boczne pogarsza ostrość oraz kontrast obrazu radiograficznego (rys. 3 ).

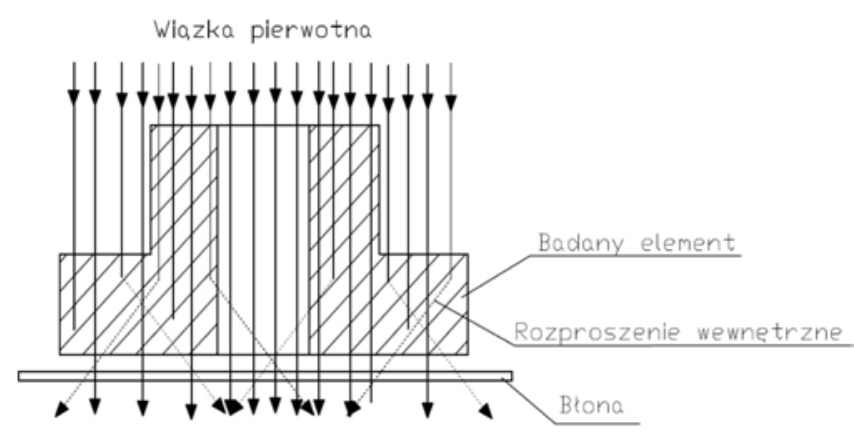

Rys. 1. Rozproszenie wewnętrzne promieniowania [4]

Fig. 1. Internal radiation scattering [4]

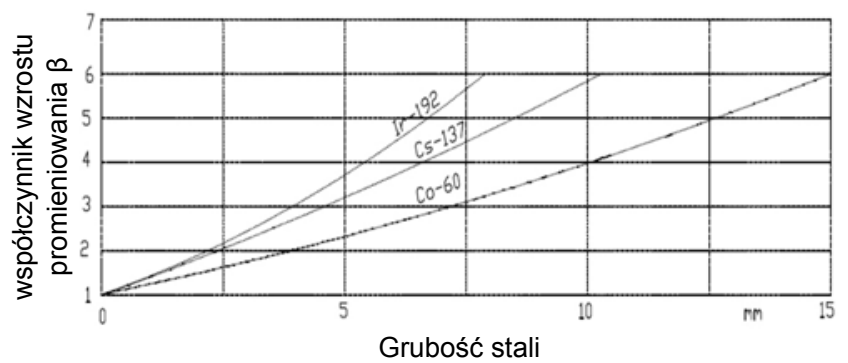

Rys. 2. Współczynnik wzrostu promieniowania w zależności od energii promieniowania i grubości stali [4]

Fig. 2. The coefficient of radiation increase, depending on radiation energy and steel thickness [4]

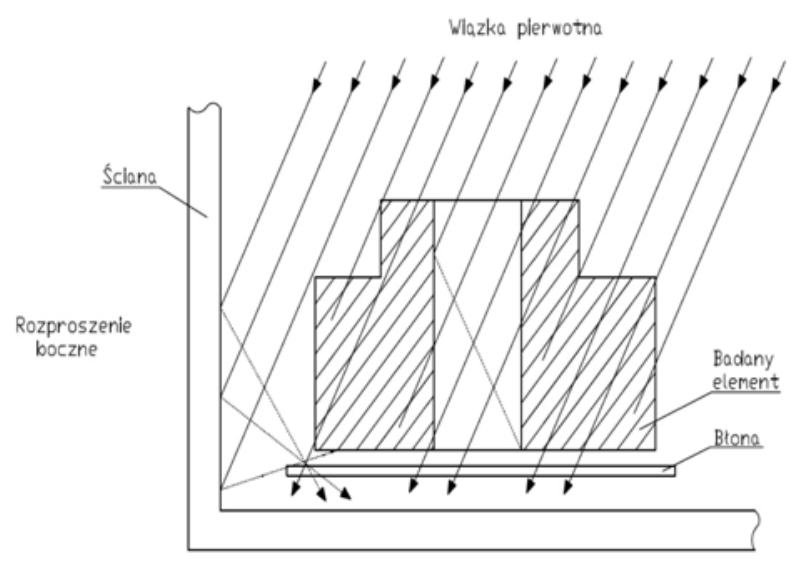

Rys. 3. Rozproszenie boczne promieniowania [4]

Fig. 3. Side scattering of the radiation [4]

Wiązka pierwotna

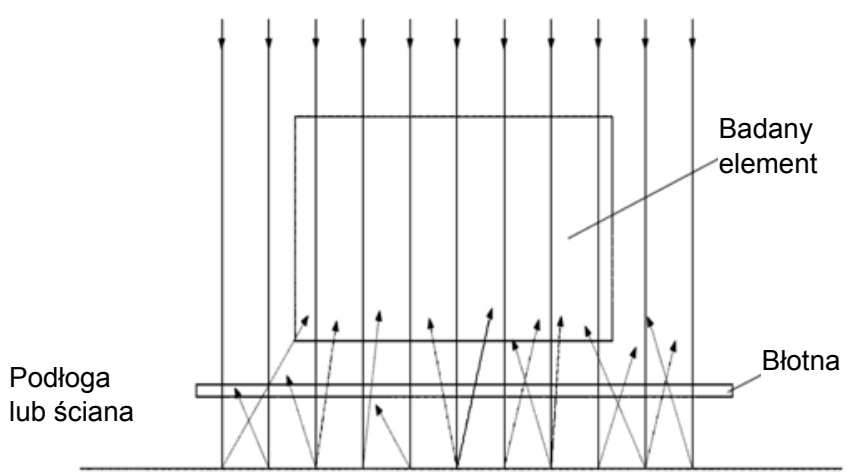

Rys. 4. Rozproszenie wsteczne promieniowania [4]

Fig. 4. Backscattering of the radiation [4]

Rozproszenie wsteczne - jest to rozproszenie promieniowania od powierzchni lub obiektów znajdujących się bezpośrednio za badanym elementem (rys. 4).

Rozproszenie wsteczne powoduje pogorszenie ostrości i kontrastu obrazu radiograficznego, a także powstawanie na radiogramie dodatkowych obrazów wad pozornych.

\section{Oddziaływania fizyczne}

Osłabienie promieniowania przy przejściu przez materię jest wynikiem przede wszystkim wzajemnie niezależnych procesów, tj. efektu fotoelektrycznego, efektu Comptona i zjawiska tworzenia par. 


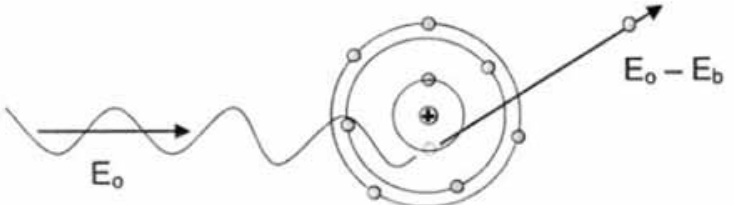

Rys. 5. Efekt fotoelektryczny [3]

Fig. 5. Photoelectric effect [3]

a)

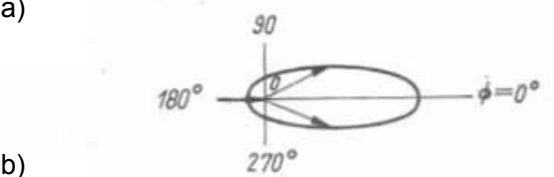

b)

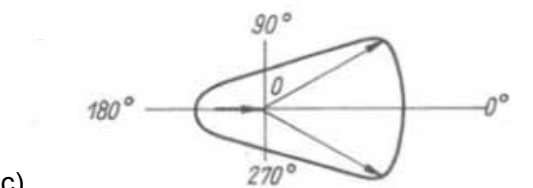

c)

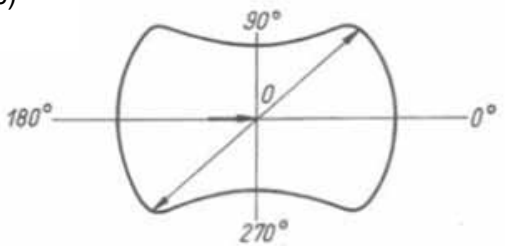

Rys. 6. Rozkład kierunkowy promieni rozproszonych w zjawisku Comptona dla różnych energii fotonu: a) $4,5 \mathrm{MeV}$, b) 0,6 MeV, c) $5 \mathrm{keV}$ [4] Fig. 6. Directional distribution of scattered rays for Campton effect for different photon energy: a) 4,5 MeV, b) 0,6 MeV, c) $5 \mathrm{keV}$ [4]

Efekt fotoelektryczny - rodzajem oddziaływania w zakresie niższych energii promieniowania rentgenowskiego (rys. 5). Elektron jest wybijany przez padający foton z powłoki atomu. Jego energia zostaje przekazana elektronowi - częściowo na pokonanie energii wiązania oraz częściowo w postaci energii kinetycznej. Foton znika wtedy. Energia kinetyczna elektronu zostaje natomiast zużyta na jonizację i wzbudzanie spotykanych atomów.

Efekt fotoelektryczny bezpośrednio nie generuje promieniowania rozproszonego, jednak może wywoływać wtórne promieniowanie fotoluminescencyjne [3]. Puste miejsca, jakie zostają po wybitych elektronach, są zapełniane przez elektrony $z$ wyższych pasm energetycznych, w wyniku czego powstają fotony promieniowania o energii równej różnicy poziomów, między którymi następuje przejście elektronu.

Promieniowanie to nie ma istotnego znaczenie dla promieniowania rozproszonego, które jest rejestrowane poza obiektem na błonie, ponieważ ma małą energię i jest szybko wchłaniane przez najbliższe otoczenie.

Efekt fotoelektryczny nie przyczynia się więc do generowania promieniowania rozproszonego i w tym sensie jest nieszkodliwy dla badań radiograficznych [3].

Efekt Comptona - w średnim i wyższym zakresie energii promieniowania dominującym rodzajem oddziaływania jest efekt Comptona.

Polega on na wybiciu elektronu z zewnętrznej powłoki atomu kosztem części energii fotonu.
Foton nie znika całkowicie, zmienia swój kierunek i energię. Energie wiązania elektronów w zewnętrznych powłokach atomu są bardzo małe $\mathrm{w}$ porównaniu $\mathrm{z}$ energią fotonu zanikającego. Można więc przyjąć, że rozpraszanie następuje na swobodnych elektronach i energia fotonu rozproszonego jest mniejsza od energii fotonu zanikającego o wartość równą energii kinetycznej wybitego elektronu [3].

W miarę przechodzenia promieniowania rozproszonego przez materię przedłuża się jego wzajemne oddziaływanie z elektronami materii, pojawiają się fotony wtórnego i wielokrotnego rozpraszania. Oddziaływanie fotonów promieniowania rozproszonego z materią zwykle kończy się fotoefektem [4].

Zjawisko Comptona powoduje, że część promieniowania pierwotnego przemienia się $\mathrm{w}$ promieniowanie bardziej miękkie, o różnych długościach fal, skierowane w różnych kierunkach, czyli w promieniowanie rozproszone [4].

$\mathrm{Na}$ rysunku 6 przedstawiono rozkład kierunkowy promieni rozproszonych we współrzędnych biegunowych w zależności od ich energii pierwotnej. Odległość poszczególnych punktów na krzywych od punktu 0 jest proporcjonalna do natężenia promieni rozproszonych w danym kierunku. Miękkie promienie są silnie rozpraszane we wszystkich kierunkach. Natężenie promieni rozproszonych w kierunku wiązki pierwotnej i w przeciwnym jest prawie dwa razy większe niż w kierunkach prostopadłych. Większa część promieniowania jest rozpraszana w kierunku wiązki pierwotnej wtedy, kiedy twardsze jest promieniowanie pierwotne.

Promieniowanie rozproszone $w$ różnych kierunkach jest niepożądane, gdyż powoduje pogorszenie ostrości i kontrastu obrazu radiograficznego.

Rozpraszanie Comptona prowadzi do dużych zmian zarówno energii, jak i kierunku fotonów padających. Efekt Comptona jest głównym źródłem promieniowania rozproszonego w przemysłowych badaniach radiograficznych.

Zjawisko tworzenia par - polega na całkowitej zamianie energii fotonu padającego na wytworzenie pary cząstek elektron-pozyton oraz na energię kinetyczną obu tych cząstek (rys. 7). Zjawisko takie może zajść w silnym polu elektrycznym w pobliżu jądra atomowego pod warunkiem, że energii fotonu wystarczy na wytworzenie pary cząstek elektron-pozyton [3]. W wyniku opisanego procesu foton zanika, natomiast dwie pozostałe cząstki rozbiegają się w różnych kierunkach, unosząc ze sobą energię kinetyczną. Prawdopodobieństwo powstania par wzrasta ze wzrostem energii fotonów, jednak efekt ten staje się dominujący dopiero przy energiach rzędu kilku MeV. Wynika więc $z$ tego, że efekt ten nie występuje wcale lub ma bardzo małe znaczenie $w$ badaniach radiograficznych wykonywanych za pomocą lamp rentgenowskich lub źródeł promieniowania gamma. Ma natomiast znaczenie $w$ badaniach wykonywanych za pomocą źródeł wysokoaktywnych, takich jak: betatrony czy akceleratory liniowe. 


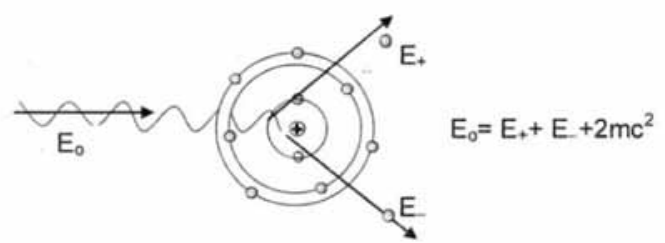

Rys. 7. Schemat tworzenia pary elektron-pozyton w polu elektrycznym jądra atomowego [3]

Fig. 7. Creation scheme of the pair of electrons-the positron in the electric field of the atom [3]

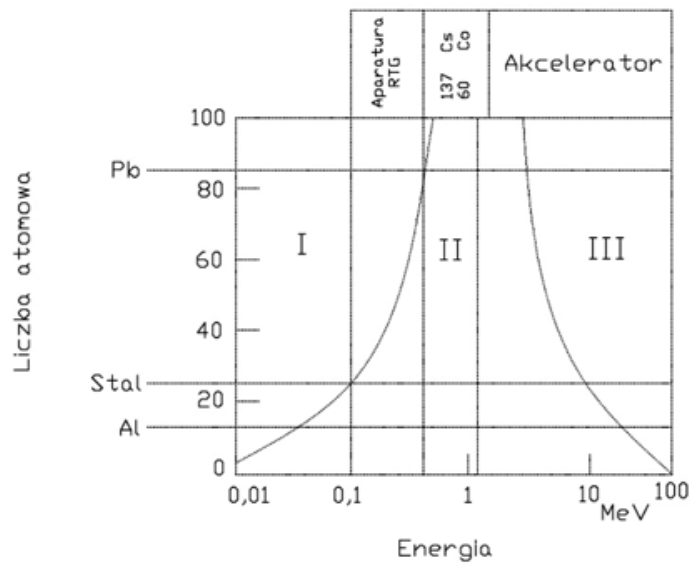

Rys. 8. Względny udział poszczególnych procesów oddziaływania promieniowania elektromagnetycznego z materią: I - przewaga zjawiska fotoelektrycznego, II - przewaga zjawiska - Comptona, III - przewaga zjawiska tworzenia par [4]

Fig. 8. Relative participation of particular electromagnetic interaction processes with matter: I - photoelectric effect domination, II Compton effect domination, III - pair-production effect domination [4]

Względny udział poszczególnych procesów oddziaływania promieniowania elektromagnetycznego z materia w sposób istotny zależy od liczby atomowej materiału (rys. 8). W warunkach przemysłowych przy prześwietlaniu wyrobów ze stali, metali lekkich lub materiałów wysokopolimerowych główny udział w osłabianiu promieniowania ma zjawisko rozproszenia Comptona [4].

We wszystkich przypadkach oddziaływania promieniowania elektromagnetycznego z materią, końcowym efektem jest uwalnianie elektronów, a więc jonizacja materii. Uwolniony z dostatecznie dużą energią kinetyczną elektron wywołuje dalsze jonizacje. Pojedyncza jonizacja wywołana przez foton właściwie nie ma znaczenia w porównaniu z jonizacją wywołaną wtórnie przez uwolnione elektrony. Promieniowanie elektromagnetyczne nie jonizuje bezpośrednio, lecz pośrednio za pomocą wtórnych elektronów.

\section{Praktyczne skutki promieniowania rozproszonego}

Najpoważniejszą wadą występowania promieniowania rozproszonego jest obniżenie kontrastu radiograficznego uzyskiwanego na błonie radiograficznej.
Błona radiograficzna powinna być osłaniana przed działaniem promieniowania rozproszonego, które znacznie pogarsza jakość obrazu radiograficznego. Osłanianie polega na umieszczeniu za układem błona - okładka ekranu: ołowianego o grubości $\mathrm{g} \geq 1 \mathrm{~mm}$ lub cynowego o grubości $\mathrm{g} \geq 1,5 \mathrm{~mm}$ [5].

Występowanie promieniowania rozproszonego powinno być sprawdzane w przypadku każdego nowego układu badawczego $z$ zastosowaniem ołowianej litery $B$, umieszczonej bezpośrednio za każdą kasetą, o wysokości co najmniej $10 \mathrm{~mm}$ i grubości min. $1,5 \mathrm{~mm}$. Jeżeli obraz tej litery na radiogramie jest jasny, to radiogram charakteryzuje się niską jakością (dużym zadymieniem) i powinien być odrzucony. Jeżeli obraz litery jest ciemny lub niewidoczny, to radiogram dobrze zabezpieczono przed działaniem promieniowania rozproszonego i powinien być zaakceptowany.

\section{Badania laboratoryjne}

W laboratorium badań nieniszczących przeprowadzono badania wpływu promieniowania rozproszonego na jakość obrazu radiograficznego.

\section{Wpływ promieniowania rozproszonego od obiektów znajdujących się poza błoną na jakość obrazu na radiogramie}

Wykonano badania radiograficzne dla następującego elementu:

płyta stalowa (oznaczona jako próbka nr 1 o grubości $15 \mathrm{~mm}$, odległość źródło - błona (ogniskowa) $\mathrm{f}=700 \mathrm{~mm}$, błona D5 Kodak T200, czas ekspozycji $3,40 \mathrm{~min}$, parametry ekspozycji: $200 \mathrm{kV}, 4 \mathrm{~mA}$ - aparat rentgenowski ICM Site XS.

Badanie wykonano na podłożu $z$ betonu na próbce $\mathrm{nr} 1$, umieszczając za błoną płytę ołowianą (rys. 9). Po obróbce fotochemicznej uzyskano obraz na radiogramie o gęstości optycznej $D=2,6$. Widoczny jest ciemny obraz litery B (zastosowana technika eliminuje promieniowanie rozproszone).

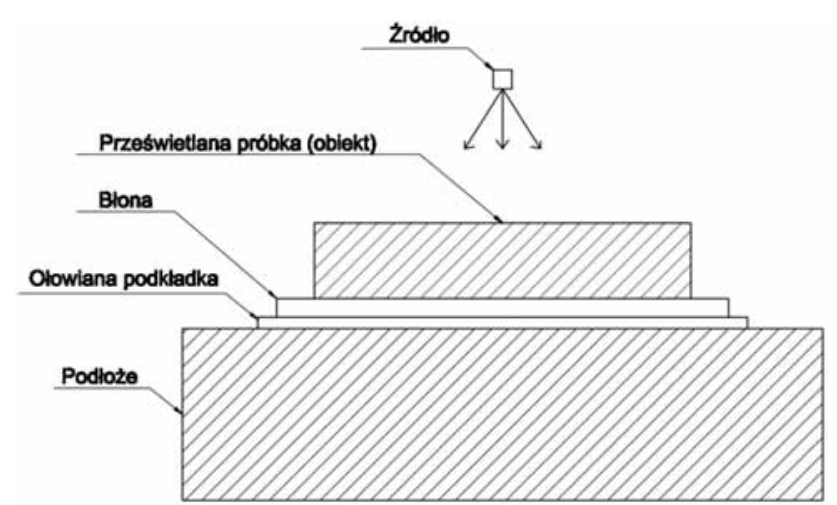

Rys. 9. Schemat badania próbki $\mathrm{nr} 1$

Fig. 9. Specimen No 1 testing scheme 


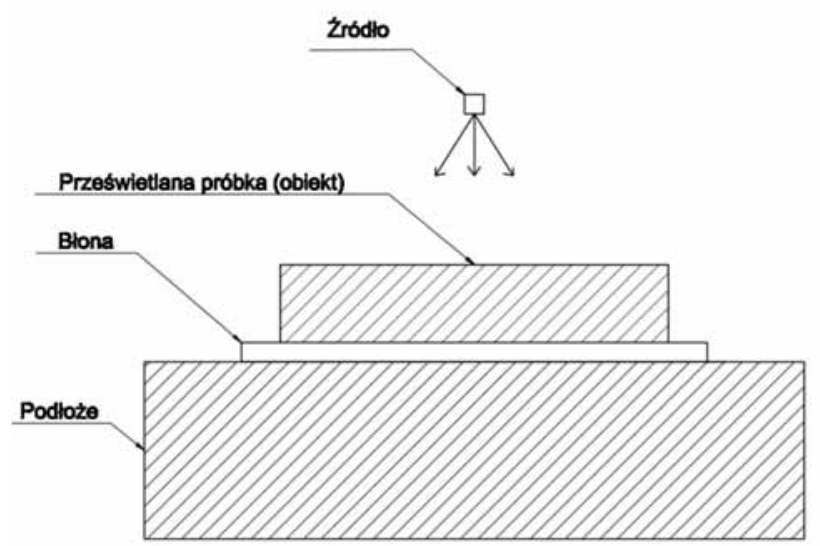

Rys. 10. Schemat badania próbki $\mathrm{nr} 2$

Fig. 10. Specimen No 2 testing scheme

Próbkę nr 2 umieszczono bezpośrednio na podłożu $z$ betonu - zgodnie z rysunkiem 10. Po obróbce fotochemicznej uzyskano obraz na radiogramie o gęstości optycznej $D=4,1$.

Widoczny jest jasny obraz litery B (zastosowana technika nie eliminuje promieniowania rozproszonego).

\section{Niezgodności w obliczeniach czasów ekspozycji}

Badano wpływ promieniowania rozproszonego na jakość obrazu na radiogramie przy zastosowaniu różnych układów badań zgodnie z normą PN EN 1435.

Próbkę płyty umieszczono na wysokości $1 \mathrm{~m}$ od podłoża. Zastosowano układ badań wg PN EN 1435 (rys. 11).

Po obróbce fotochemicznej uzyskano obraz na radiogramie o gęstości optycznej $D=2,2$.

Wykonano badania radiograficzne dla następującego elementu:

rura stalowa $\varnothing 168 \times 7,5$ (oznaczona jako próbka nr 4), o grubości 7,5 mm, odległość źródło - błona (ogniskowa) $\mathrm{f}=700 \mathrm{~mm}$, błona D5 Kodak T200, czas ekspozycji 3,40 min, parametry ekspozycji: $200 \mathrm{kV}$, $4 \mathrm{~mA}$ - aparat rentgenowski ICM Site XS.
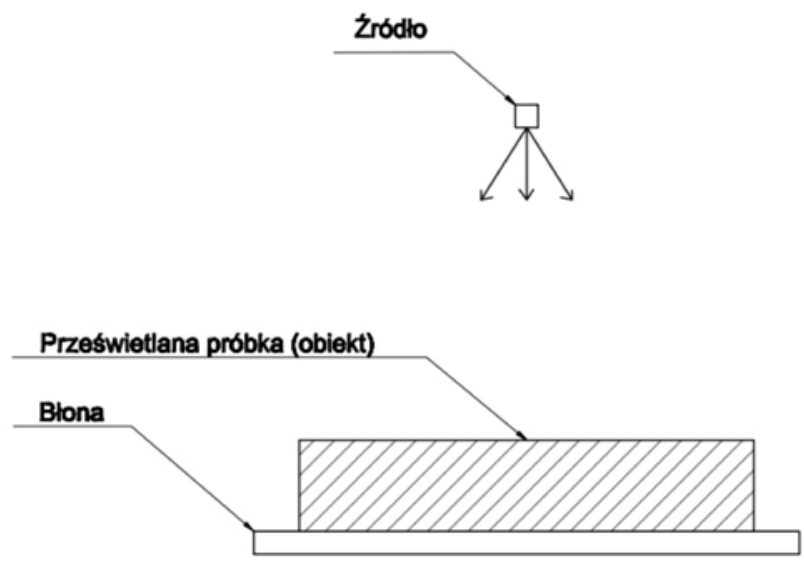

Rys. 11. Schemat badania próbki $\mathrm{nr} 3$

Fig. 11. Specimen No 3 testing scheme

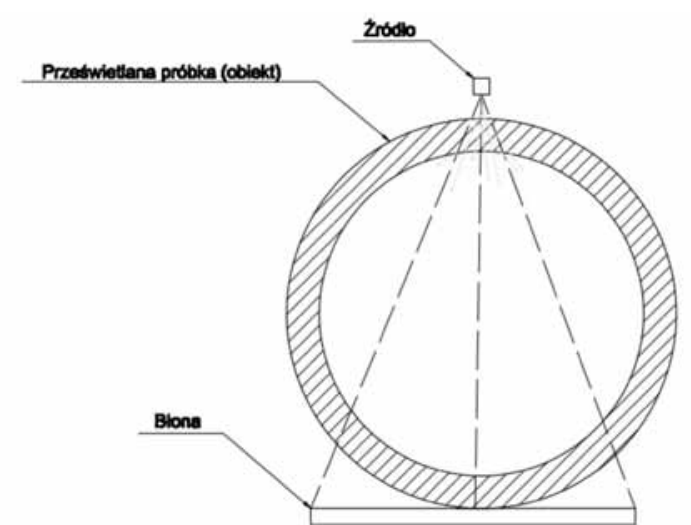

Rys. 12. Schemat badania próbki $\mathrm{nr} 4$

Fig. 12. Specimen No 4 testing scheme

Zastosowano układ badań przedstawiony na rysunku 12 (technika ekspozycji przez 2 ścianki) - PN EN 1435. Po obróbce fotochemicznej uzyskano obraz na radiogramie o gęstości optycznej $D=1,5$.

\section{Wnioski}

Przy prześwietleniu płyty stalowej o tej samej grubości $15 \mathrm{~mm}$ oraz wykonywaniu prześwietlenia przy zastosowaniu tych samych parametrów, dla próbki $\mathrm{nr} 1$ uzyskano gęstość optyczną $D=2,6$, natomiast dla próbki nr 2 uzyskano gęstość optyczną $D=4,1$. W przypadku pierwszym występuje ciemny obraz litery $B$, natomiast $w$ drugim - jasny obraz litery $B$. W przypadku drugim zastosowana technika nie eliminuje promieniowania rozproszonego od obiektów znajdujących się poza błoną, np. podłogi betonowej. Aby uzyskać odpowiednią jakość obrazu na radiogramie, należy zastosować płytę ołowianą umieszczoną za błoną.

Przy prześwietlaniu próbki nr 3 - płyty stalowej o grubości $15 \mathrm{~mm}$ zastosowano układ badań na rysunku 11 (PN EN 1435) i próbki nr 4 - rury ø168x7,5 (grubość prześwietlana wynosi $15 \mathrm{~mm}$ ) zastosowano układ badań wg rysunku 12 (PN EN 1435). Dla płyty uzyskano gęstość optyczną $D=2,2$, a dla rury $\mathrm{D}=1,5$. W przypadku badania rury ze stożka wiązki wychodzi prawie całe promieniowanie rozproszone w pierwszej ściance, która znajduje się w pobliżu źródła promieniowania. Promieniowanie to nie dociera do filmu i nie wpływa nazaczernienie radiogramu. Różnica w gęstości optycznej wynosi ok. 35\% przy tej samej grubości prześwietlanej, ale przy innych układach badań. Aby uzyskać prawidłowy obraz na radiogramie, należałoby zwiększyć czas ekspozycji o ok. $35 \%$ w układzie badań nr 13 (metoda obwodowa - prześwietlanie przez dwie ścianki) PN-EN 1435.

Z wyników badań widać, że wpływ promieniowania rozproszonego na wyniki obliczeń czasów ekspozycji jest dość duży, a brak jego uwzględnienia może doprowadzić do znaczących błędów w ekspozycji radiogramów 


\section{Podsumowanie}

W wyniku badań przeprowadzonych w laboratorium zwrócono szczególną uwagę na dwa ważne w praktyce skutki występowania promieniowania rozproszonego:

- wyeliminowanie promieniowania rozproszonego od obiektów znajdujących się poza błoną, jak podłoga czy ściana, np. przez zastosowanie płyty ołowianej umieszczonej za błoną,

- korekcję czasów ekspozycji dla różnych technik radiograficznych.

\section{Literatura}

[1] PN-EN 444 Badania nieniszczące. Ogólne zasady radiograficznych badań materiałów metalowych za pomoca promieniowania $\mathrm{X}$ i gamma.

[2] Nondestructive Testing Handbook, vol. 4, Radiographic Testing, American Society for Nondestructive Testing 2002.

[3] Mackiewicz S.: Promieniowanie rozproszone i jego rola w badaniach radiograficznych. Krajowa Konferencja Badań Radiograficznych Popów 2010.

[4] Jezierski G.: Radiografia przemysłowa. Wydawnictwa Naukowo-Techniczne, Warszawa 1993.

[5] PN-EN 1435 Badania nieniszczące złączy spawanych. Badania radiograficzne złączy spawanych.

[6] Czuchryj J., Dębski E.: Badania złączy spawanych według norm europejskich. Biuro Gamma, Warszawa 2000.

\section{\$\& 4METAL.PL}

\section{Ponad 2000 podwykonawców z całego świata}

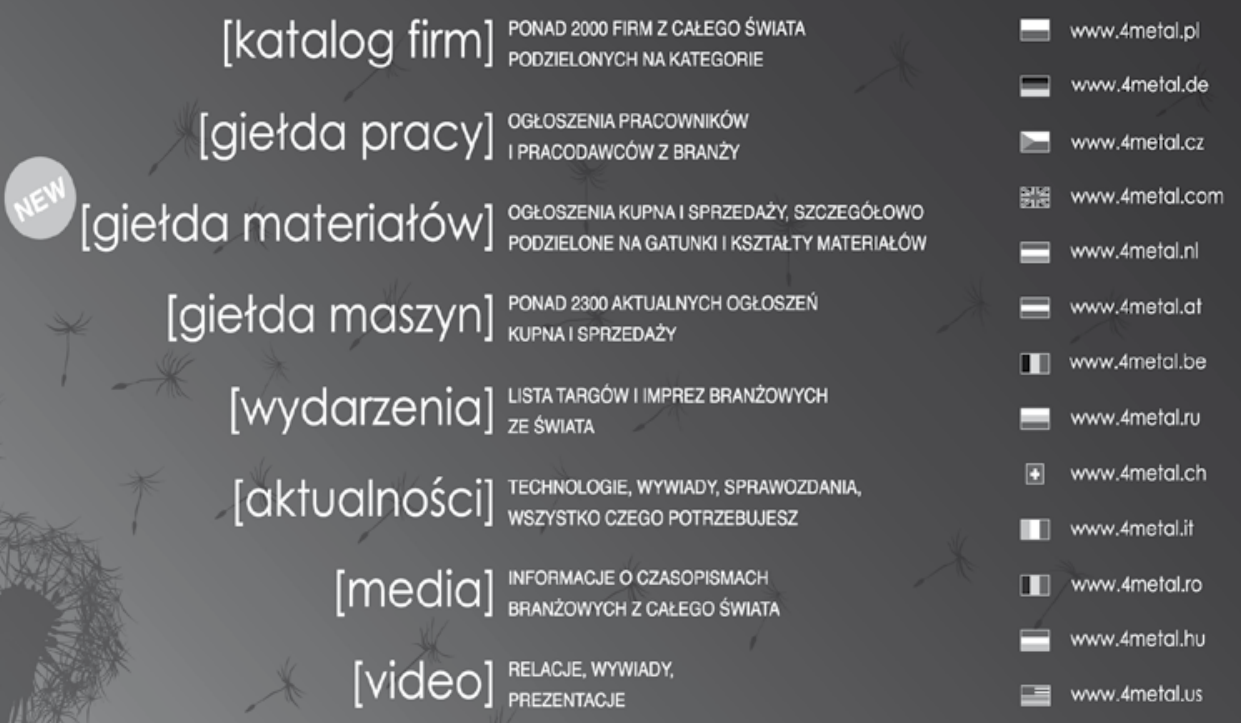

